\title{
BMJ Open Experience of fatigue and associated factors among adult people living with HIV attending ART clinic: a hospital- based cross-sectional study in Ethiopia
}

\author{
Moges Baye, ${ }^{1}$ Berihu Fisseha, ${ }^{2}$ Mulugeta Bayisa, ${ }^{1,3}$ \\ Solomon Mekonnen Abebe (D) , ${ }^{4}$ Balamurugan Janakiraman (D) ${ }^{2}$
}

To cite: Baye M, Fisseha B, Bayisa M, et al. Experience of fatigue and associated factors among adult people living with HIV attending ART clinic: a hospital-based cross-sectional study in Ethiopia. BMJ Open 2020;10:e042029. doi:10.1136/ bmjopen-2020-042029

- Prepublication history and additional material for this paper is available online. To view these files, please visit the journal online (http://dx.doi.org/10. 1136/bmjopen-2020-042029)

Received 23 June 2020 Revised 22 August 2020 Accepted 24 August 2020

\section{Check for updates}

(c) Author(s) (or their employer(s)) 2020. Re-use permitted under CC BY-NC. No commercial re-use. See rights and permissions. Published by BMJ.

${ }^{1}$ Department of Physiotherapy, School of Medicine, College of Medicine and Health Sciences, and Specialized Hospital, Gondar, Amhara, Ethiopia ${ }^{2}$ Department of Physiotherapy, School of Medicine, College of Health Sciences and Ayder Comprehensive Specialized Hospital, Mekelle University,

Mekelle, Tigray, Ethiopia

${ }^{3}$ School of Rehabilitation Therapy, Queen's University, Kingston, Ontario, Canada ${ }^{4}$ Institute of Public Health, College of Medicine and Health Sciences, University of Gondar, Gondar, Ethiopia

Correspondence to Dr Balamurugan Janakiraman; bala77physio@gmail.com

\section{ABSTRACT}

Objective This study aimed to determine the prevalence of fatigue and the factors associated among adult people living with HIV attending antiretroviral therapy clinic in Gondar town, Ethiopia.

Design Cross-sectional.

Setting Governmental health facility that provides HIV care in Gondar town.

Outcome measure Fatigue is defined by nine items version Fatigue Severity Scale.

Participants Adult (aged 18 and above) people living with HIV in Gondar town ( $n=392)$.

Result A total of 408 HIV seropositive adults were approached for consent, among which 392 participants consented to participate in this study, with a response rate of $96.1 \%$. The mean age of the participants was $40.5 \pm 8.5$ years. The prevalence of HIV-related fatigue was $53.3 \%$ and about $66 \%$ of women living with HIV experienced fatigue. The factors associated with fatigue experience were; female gender (adjusted OR (AOR): $2.61,95 \% \mathrm{Cl}$ 1.01 to 5.3 ), being married (AOR: $0.18,95 \% \mathrm{Cl} 0.10$ to 0.9 ), low income (AOR: $7.1,95 \% \mathrm{Cl} 4.6$ to 22.15 ), unemployed (AOR: $2.79,95 \% \mathrm{Cl} 1.19$ to 9.84 ), parity (AOR: $4.87,95 \% \mathrm{Cl}$ 2.18 to 17.9 ), being anaemic (AOR: $12.45,95 \% \mathrm{Cl} 5.6$ to 41.01), depression (AOR: $4.51,95 \% \mathrm{Cl} 1.91$ to 11.20 ), mild weight loss (AOR: $4.295 \% \mathrm{Cl} 2.56$ to 13.9) and moderate weight loss (AOR: $5.1,95 \% \mathrm{Cl} 1.85$ to 16.12 ), respectively. Conclusion The findings of this study revealed that experiencing fatigue is quite common among adult people living with HIV. It is important for the healthcare professionals and people living with HIV to understand; the possible causes of fatigue, remedies and ways to reclaim energy. The predisposing factors and complications that cause fatigue should be aggressively diagnosed and treated by the clinicians. Further qualitative studies exploring the reasons for experiencing HIV-related fatigue might help designing interventions.

\section{INTRODUCTION}

Globally by the end of 2018, about 37.9 million people were reported to live with HIV and the highest-burden of it is carried by subSaharan Africa (SSA) with an estimated $71 \%$ of the global tally. ${ }^{1}$ SSA remains a hotspot of the pandemic and nearly one in every 25
Strengths and limitations of this study

- The cross-sectional nature of this study is not sufficient to infer the causality of HIV-related fatigue.

- The wider $\mathrm{Cl}$ for the OR of some variables suggests replication of the study using a larger sample size.

- The strengths of this study are: this study has provided a well-powered insight into the prevalence of fatigue and factors associated among the people living with HIV using a representative sample of the clinical population and a valid outcome tool. This should enhance the external validity of the findings.

adults living (3.9\%) with HIV. A 2018 report estimated that 722248 Ethiopian adults live with HIV and the distribution is skewed with the high cluster in the urban areas. Further, the prevalence of HIV in urban areas of the Amhara regional state was $4 \%$ in 2017 and the study area (North Gondar Zone) is a hotspot cluster and also mapped as a geospatial prioritised zone. The HIV/AIDS Prevention and Control Office of Ethiopia in 2019 reported that the reduction in HIV-related mortality and morbidity is being challenged due to complacency. ${ }^{2-5}$

Fatigue is a perceived phenomenon and often self-reported, which is defined as a subjective sensation of weariness, increased sense of effort, effort-performance mismatch or exhaustion. ${ }^{6}$ 'Fatigue does not kill but it is a common, very disabling and debilitating symptom'. ${ }^{78}$ Fatigue is one of the common disabling symptoms among many chronic diseases including HIV infection. ${ }^{9}{ }^{10}$ Highly active antiretroviral therapy (HAART) introduction has faded the HIV-related mortality. ${ }^{11}{ }^{12}$ Nonetheless, the chronicity of HIV infection post-HAART era and side effects has imposed an additional burden of HIV-related symptoms. Several studies report an estimated prevalence of fatigue ranging 
from $33 \%$ to $88 \%^{813-15}$ and the fatigue is the highest reported among the other entire HIV-related and ARTrelated symptoms in HIV positive patients. ${ }^{16}$

A previous study from a different region in Ethiopia reported the prevalence of fatigue among adults living with HIV to be $51.7 \% .{ }^{17}$ The prevalence of fatigue among patients with HIV and predictors vary widely across countries and regions in the country. Several studies have reported that fatigue can negatively impact the patient's activities of daily living, quality of life, sociability, job desire, productivity, level of physical activity, psychological well-being, health-seeking behaviour and adherence to the HAART regimen. ${ }^{15} 16$ 18-21 The cause of fatigue among people living with HIV is probably multifactorial. Most of the studies focused on the physiological and/or psychological factors. ${ }^{20} 2223$ Further, evidence suggests that + fatigue is associated with age, gender, malnutrition, insomnia, unemployment, poor income, family burden, depression, social support system, several disease-related factors such as the stage of the disease, anaemia, the use of ART and certain laboratory parameters, as well as with the sociodemographic and psychological factors. ${ }^{8913} 14$

The attention in HIV care is now shifting towards symptom control and improving the quality of life of HIV infected patients elsewhere. ${ }^{24} \mathrm{SSA}$ is the hotspot of the HIV/AIDS pandemic and a large number of people living with HIV reside in Ethiopia. ${ }^{25}{ }^{26}$ Yet, there is a dearth of research in Ethiopia focusing on HIV-related fatigue as a primary outcome of interest and the study area is a challenging geographical terrain where fatigue can be very disabling. The objective of this study was to determine the prevalence of fatigue defined by the Fatigue Severity Scale (FSS) and the factors associated among adults living with HIV attending ART at the public health facility of Gondar city, Amhara, Northwest Ethiopia.

\section{METHODS}

\section{Study design, setting and population}

An institutional-based cross-sectional design study was conducted from March to May 2019 at the ART clinic, University of Gondar Specialized Comprehensive Hospital (UOGSCH). The hospital is found in Gondar town at $748 \mathrm{~km}$ far from Addis Ababa, a capital city of Ethiopia, to the northwest, at an altitude of $2706 \mathrm{~m}$ above sea level. UOGSCH is a 550 bedded multidisciplinary specialised governmental teaching hospital. Presently, it provides healthcare services to more than 5 million urban and rural inhabitants in its catchment area. ${ }^{19} 20$ The HIV care unit and ART clinic started in 2003. As of 2018, this institution has served about 11277 people living with HIV, on average $90-130$ patients every working day. This hospital provides cost-free HIV testing, CD4 count monitoring regularly, medical consultations, counselling and ART medications. Each participant signed the written consent before participation. Adult HIV seropositive outpatients diagnosed by the infectious disease physicians and registered in ART clinic, both genders aged 18 and above, lived in the sampled region for 6 months, conscious and able to speak Amharic (local language) and attending UOGSCH ART clinic were eligible for inclusion. Pregnant women, individuals with cognitive impairment and hospitalised HIV-positive patients were excluded from participation. During the sample enrolment interval (1 March 2019 to 31 May 2019), 3526 HIV-seropositive individuals registered in the ART (ART) clinic, UOGSCH.

\section{Patient and public involvement}

This study was conducted without patient or public involvement.

\section{Sampling and data collection}

The sample required for this study was estimated using a single population proportion formula. ${ }^{27}$ Since there were no similar regional studies, the following assumptions were made: $50 \%$ proportion, with a $95 \%$ CI $(Z \alpha / 2=1.96)$, and a marginal error of $5 \%$. Since the population is $<10000$ (finite population) a correction formula was used.

$$
N=\left(\frac{Z \alpha}{2}\right)^{2} \times p P(1-P) / d 2
$$

The derived power calculated sample was $\mathrm{n}=371$. Accordingly, the final sample size with added $10 \%$ contingency was found to be 408 . From the registered list of people living with HIV attending the HIV care/ART clinic each day during the study period, Kth patient was selected and the 1st participant between 1 and Kth was randomly selected, then taking every Kth number thereafter. Data were collected by two trained physiotherapists who were randomly recruited from the registered list of data collectors and were paid per diem. Interview method, measurements and a structured questionnaire were used for data collection. Sociodemographic and clinical information (comorbid, duration of illness, stage, CD4 count, viral loads, prophylaxis history, haematological values) were extracted from the patients' medical records, ART logbook and follow-up cards. FSS for measuring fatigue, Patient's Questionnaire-9 for measuring depression and Insomnia Severity Scale were also used.

\section{Variable definitions}

Fatigue is defined using the 9-item FSS. ${ }^{28}$ Each item in FSS is scored on a 7-point Likert scale ranging from 1 ('strongly disagree') to 7 (strongly agree) on how much fatigue affects the activities and lifestyle of a person. ${ }^{29} 30$ The minimum score is ' 1 ' and the maximum score is ' 63 ', another way of scoring is by calculating the mean of all the scores with ' 1 ' and ' 7 ' being the minimum and maximum scores, respectively. A cut-off score of 4 or more was considered indicative of problematic fatigue. ${ }^{29}$ A patient was considered physically active if the participant reported activity $\geq 150$ min per week. ${ }^{31}$ The Patient Health Questionnaire-9 (PHQ-9) was used to measure the depression level (case cut-off $\geq 5$ ) of the participants. ${ }^{32}$ A participant who scored $>7$ on the Insomnia Severity Scale was defined as an insomnia case. Anaemia was defined according to 
WHO criteria. For men, anaemia was defined as haemoglobin concentration $(\mathrm{Hb})$ less than $13 \mathrm{~g} / \mathrm{dL}$, while for women; the cut-off is less than $12 \mathrm{~g} / \mathrm{dL}^{33}$ Adults living with HIV suffering profound weight loss or wasting were recognised using a set of rules/criteria developed by the expert physicians in the HIV care clinic, UOGSCH and investigators of this study (online supplemental file 1). The criteria to define weight loss included (1) previously diagnosed conditions related to weight loss (six conditions), (2) intake of medications prescribed for weight gain (nine medications), (3) prescribed nutritional therapy or high calorie supplements. Categorisation of the HIV associated weight loss was based on; presence of one of the criteria in the past year as mild weight loss, two criteria in the past year as moderate criteria and more than two criteria in the past year as severe weight loss.

\section{Statistics}

Data were coded and entered into EPI Info V.7.0 and exported to IBM Statistical Package for Social Sciences (SPSS) V.24 for Windows. The representativeness of the study sample to the research setting population during the study period was examined using formulas proposed by Cochrane to calculate the normal approximation frequency. ${ }^{34}$ Sample characteristics were described with the frequency, mean and $\chi^{2} / \mathrm{t}$-test. Collinearity diagnostics were performed for each of the variables in the full model. All variance inflation factors were $<10$, and the condition inflation factors were $<30$, indicating that multicollinearity was not a problem for this model. With fatigue (categorised: yes vs no) as the dependent variable, univariate and multivariable logistic regression analyses (backward stepwise) were carried out to examine the association with different independent variables. Variables were entered into the model using forced entry and categories were used as covariates for detailed analyses. Model fit was assessed by the Hosmer and Lemeshow's goodness of fit test $\mathrm{t}^{35}$ and results were considered statistically significant when $95 \%$ CIs not containing unity (equal to $p$ value $<0.05) \cdot \chi^{2}$ test or Fisher's exact test was used to determine the prevalence distribution of fatigue and estimate its association with different predictor variables. Predictor variables that were found to be associated with HIV-related fatigue (categorised; yes or no) in univariate model were gender, marital status, income, educational status, occupation, having children, anaemia, weight loss, total duration since HIV confirmed, comorbid condition (hypertension, diabetes mellitus, respiratory conditions, cardiac conditions, arthritis), WHO classification clinical stage of HIV/AIDS and CD4 counts and the same were included in the multivariable analysis. Interaction terms were used to examine the potential association between predictor variables and fatigue. When a clear sub-group seemed present in the data set, significance testing (Pearson $\chi^{2}$ ) and, if appropriately sized subgroups per category remained, the same was exported to the logistic model. This study is reported as per the Strengthening the Reporting of Observational Studies in Epidemiology reporting guidelines (online supplemental file 2).

\section{RESULTS}

\section{Sociodemographic characteristics}

A total of 408 HIV positive adults were approached for consent, among which 392 participants consented to participate in this study, with a response rate of $96.1 \%$ and this is more than $100 \%$ of the power calculated sample size $(n=371)$. Those 16 patients who did not consent or agree to participate in the study reasoned lack of interest and time constrain.

The mean age of the participants was $40.5( \pm 8.5)$ years and majority of the participants $259(66.1 \%)$ were women. Only $7.9 \%$ of them reported to be from rural, majority of the participants were underweight (52.8\%), above one-fourth did not have formal education. About $47 \%$ reported to be jobless and $43 \%$ answered to have a low income $(<1500$ Ethiopian birr). The majority of the participants $77.3 \%$ reported a lack of family support. Most of the subjects (94.1\% and $86.9 \%$ ) self-reported no previous or current smoking and alcohol habits, respectively (table 1).

\section{Clinical characteristics}

Among the total participants, $94.6 \%$ were on ART during the study period. About $40 \%$ of the participants had been diagnosed with HIV infection for $>60$ months as of May 2019. The recent CD4 cell count of $251 \quad(n=251,64 \%)$ participants was below $350 \mathrm{cell} / \mathrm{mm}^{3}$, and about $3 / 4$ th of the participants were diagnosed to be in clinical stage I and II. Majority of the participants (93\%) were diagnosed with weight loss, nearly half of them (48.7\%) had anaemia, and only $4.6 \%$ and $9.4 \%$ had been diagnosed to have diabetes mellitus and hypertension, respectively. According to the PHQ-9 score of depression, about 3/4th of the people living with HIV were found suffering from depression, of those, almost half of them had severe depression. About one in four reported to suffer insomnia $23.2 \%$ and $29.8 \%$ were physically active (table 2 ).

\section{Fatigue among people living with HIV and distribution}

Among 392 participants, 209 ( $\mathrm{n}=209$, 53.3\%; 95\% CI 48.5 to 58.5 ) reported to have the experience of fatigue. A statistically significant difference was observed in the prevalence of fatigue between the genders (men $27.1 \mathrm{vs}$ women $66.8 \%$; $\chi^{2}(1, \mathrm{n}=392)=55.7, \mathrm{p}<0.0001$, $\left.\mathrm{phi}=0.37\right)$. The majority of widowed participants reported fatigue $78.3 \%$ followed by married $55 \%$ and single $48 \%$. The experience of fatigue was higher among anaemic participants 180 (94.2\%), unemployed $157(84.4 \%)$ and those who reported a low income 147 (86.5\%). Depression was significantly associated with the experience of fatigue (depression $72.1 \%$ vs no depression $27.9 \%$; $\chi^{2}$ (1, $\mathrm{n}=392)=144.8, \mathrm{p}<0.0001$, phi $=0.61)$. The frequency distribution of fatigue symptoms for the 9-item FSS reported by the respondents was almost even and the majority of 
Table 1 Sociodemographic characteristics of people living with HIV/AIDS attending antiretroviral therapy clinic, in the University of Gondar Hospital, University of Gondar, Northwest Ethiopia, 2019 ( $n=392)$

\begin{tabular}{|c|c|c|c|c|c|}
\hline \multirow[b]{2}{*}{ Variables } & \multirow{2}{*}{$\begin{array}{l}\text { Sample total } \\
\mathrm{n}(\%)\end{array}$} & \multicolumn{2}{|c|}{ Fatigue n (\%) } & \multirow[b]{2}{*}{$\chi^{2}$} & \multirow[b]{2}{*}{$P$ value } \\
\hline & & Yes & No & & \\
\hline \multicolumn{6}{|l|}{ Sex } \\
\hline Female & $259(66.1)$ & $173(66.8)$ & $86(33.2)$ & 55.7 & 0.000 \\
\hline Male & $133(33.9)$ & $36(27.1)$ & $97(72.9)$ & & \\
\hline \multicolumn{6}{|l|}{ Age group (years) } \\
\hline$<25$ & $16(41)$ & $04(25)$ & $12(75)$ & 5.7 & 0.06 \\
\hline $25-44$ & $255(65.1)$ & $141(55.3)$ & $114(44.7)$ & & \\
\hline$\geq 45$ & $121(30.9)$ & $64(52.9)$ & $57(47.1)$ & & \\
\hline \multicolumn{6}{|l|}{ Religion } \\
\hline Orthodox & $310(79.1)$ & $164(52.9)$ & $146(47.1)$ & 0.19 & 0.91 \\
\hline Muslim & $48(12.2)$ & $18(52.8)$ & $16(47.2)$ & & \\
\hline Protestant & $34(8.7)$ & $27(56.2)$ & $21(43.8)$ & & \\
\hline \multicolumn{6}{|l|}{ Marital status } \\
\hline Single & $91(23.2)$ & $44(48.4)$ & $47(51.6)$ & 18.3 & 0.04 \\
\hline Married & $203(51.8)$ & $112(55.2)$ & $91(44.8)$ & & \\
\hline Divorced & 75 (19.1) & $35(46.7)$ & $40(53.3)$ & & \\
\hline Widowed & $23(5.9)$ & 18 (78.3) & $05(21.7)$ & & \\
\hline \multicolumn{6}{|l|}{ Level of education } \\
\hline No formal schooling & $114(29.1)$ & $68(59.6)$ & $46(40.4)$ & 7.1 & 0.044 \\
\hline Grade 1-6 & $82(20.9)$ & $38(46.3)$ & $44(53.7)$ & & \\
\hline Grade 7-8 & $53(13.5)$ & $30(56.6)$ & $23(43.4)$ & & \\
\hline Grade 9-10 & $53(13.5)$ & $32(60.4)$ & 21 (39.6) & & \\
\hline Grade 11-12 & 44 (11.2) & 19 (43.2) & $25(56.8)$ & & \\
\hline Diploma and above & $46(11.7)$ & $22(47.8)$ & $24(52.2)$ & & \\
\hline \multicolumn{6}{|l|}{ Residence } \\
\hline Urban & 361 (92.1) & $197(54.6)$ & $164(45.4)$ & 2.88 & 0.81 \\
\hline Rural & $31(7.9)$ & $12(38.7)$ & 19 (61.3) & & \\
\hline \multicolumn{6}{|l|}{$\mathrm{BMI}\left(\mathrm{kg} / \mathrm{m}^{2}\right)$} \\
\hline Underweight $(<18.5)$ & $207(52.8)$ & $26(12.6)$ & $181(87.4)$ & 292.1 & 0.000 \\
\hline Normal weight (18.5-24.9) & $172(43.9)$ & $170(98.8)$ & $02(1.2)$ & & \\
\hline Overweight (25-29.9) & $10(2.6)$ & $09(90)$ & $01(10)$ & & \\
\hline Obese (>29.9) & $03(0.7)$ & $02(66.7)$ & $01(33.3)$ & & \\
\hline \multicolumn{6}{|l|}{ Employment status } \\
\hline Unemployed & $186(47.4)$ & $157(84.4)$ & $29(15.6)$ & 137.4 & 0.000 \\
\hline Employed & $206(52.6)$ & $52(25.2)$ & $154(74.8)$ & & \\
\hline \multicolumn{6}{|l|}{ Income/wealth index } \\
\hline Low income & $170(43.4)$ & $147(86.5)$ & $23(13.5)$ & 202.5 & 0.000 \\
\hline Medium income & $91(23.2)$ & $56(61.5)$ & $35(38.5)$ & & \\
\hline High income & $131(33.4)$ & $06(4.6)$ & $125(95.4)$ & & \\
\hline \multicolumn{6}{|l|}{ Having children } \\
\hline Yes & $243(62.0)$ & $182(74.9)$ & $61(25.1)$ & 119.6 & 0.000 \\
\hline No & $149(38.0)$ & $27(18.1)$ & $122(81.9)$ & & \\
\hline \multicolumn{6}{|l|}{ Family support } \\
\hline Yes & $89(22.7)$ & $38(42.7)$ & $51(57.3)$ & 4.3 & 0.91 \\
\hline
\end{tabular}


Table 1 Continued

\begin{tabular}{|c|c|c|c|c|c|}
\hline \multirow[b]{2}{*}{ Variables } & \multirow{2}{*}{$\begin{array}{l}\text { Sample total } \\
\text { n (\%) }\end{array}$} & \multicolumn{2}{|c|}{ Fatigue $\mathrm{n}(\%)$} & \multirow[b]{2}{*}{$\chi^{2}$} & \multirow[b]{2}{*}{ P value } \\
\hline & & Yes & No & & \\
\hline No & 303 (77.3) & $171(56.4)$ & $132(43.6)$ & & \\
\hline Current smokers & $16(4.1)$ & $11(68.7)$ & 5 (31.3) & 7.8 & 0.2 \\
\hline Previous smoker & $07(1.8)$ & $4(57.1)$ & $3(42.9)$ & & \\
\hline \multicolumn{6}{|l|}{ Alcohol } \\
\hline Never & 341 (86.9) & 175 (51.3) & $166(48.7)$ & 5.4 & 0.34 \\
\hline Current & $46(11.8)$ & $31(67.4)$ & 15 (32.6) & & \\
\hline Past & 05 (1.3) & $03(60)$ & $02(40)$ & & \\
\hline
\end{tabular}

BMI, body mass index.

them reported that 'exercise brings on my fatigue' $57.4 \%$ (225/392), and 'I am easily fatigued' $55.9 \%$ (219/392) (see figure 1 ).

\section{Regression analysis}

Prior to analysis, 14 variables that are potentially related to the experience of fatigue were identified for regression analysis: gender, age, marital status, education level, employment status, income index, parity, duration of HIV, HIV/AIDS clinical-stage, weight loss, anaemia, comorbid conditions, depression and physical activity. Of those, age, duration of HIV and physical activity were found not significantly associated in univariate analyses. The remaining 11 variables independently contributed to the regression model as predictors or confounders and entered into the multivariable model. In multivariable analyses when adjusted for other independent variables; gender, marital status, income level, employment status, parity, anaemia, depression and weight loss were found to be significant predictors.

Women living with HIV were 2.6 times more likely to experience fatigue than their counterparts (adjusted OR (AOR) 2.61, 95\% CI 1.01 to 5.32), patients who were married and living with their spouse were $82 \%$ less likely to experience fatigue than those who were not with their spouse. Those who were unemployed and had low income were about three times (AOR 2.79, 95\% CI 1.19 to 9.84) and sevenfolds (AOR 7.1, 95\% CI 4.6 to 22.15) more likely to suffer from fatigue. Participants those who have children were nearly five times more likely to have fatigue compared with those who did not have children (AOR $4.87,95 \%$ CI 2.18 to 17.9 ). Those diagnosed with anaemia and depression were 12 times (AOR 12.45, 95\% CI 5.6 to 41.01 ) and 4.5 times (AOR $4.51,95 \%$ CI 1.91 to 11.2 ), respectively. Those who had mild and moderate weight loss were about five times more likely to develop fatigue as compared with those with no weight loss (AOR 4.2, 95\% CI 2.56 to 13.94 ) and (AOR 5.1, 95\% CI 1.85 to 16.12), respectively (table 3 ). The interaction effect of unemployment, low income, gender, having children and depression was not significantly associated with fatigue.

\section{DISCUSSION}

The findings of this study showed that the overall prevalence of fatigue using the 9-item FSS among people living with HIV attending the ART clinic at the UOGSCH in Gondar city, Ethiopia was $53.3 \%$ (95\% CI 48.5 to 58.4 ). This is to some extent at the higher end of the prevalence range $(33 \%-88 \%)$ reported previously in the literature. ${ }^{813-15}$ This finding is harmonised with the regional study conducted in Tigray, Ethiopia $51.7 \%$, studies in USA 54\%, South Africa 55\% and Canada 54\%. ${ }^{172936}$ Larger sample size, similar patient characteristics and inclusion criteria in these studies could explain the consistent findings.

Most of the Ethiopian adults are involved in intense activity, domestic working, home care, children care and caring for the elderly. Negative life events such as disease, debilitating symptoms, unemployment and separation from life partners would often trigger the illness. ${ }^{38} 39$ The differing health beliefs in Ethiopian culture might have influenced the cut-off of where and how fatigue and depression are perceived. Further, the FSS used in this study was translated and adapted based on the pilot study but the high level of illiteracy among the participants in this study could have influenced the prevalence rate in this study.

Surprisingly, in this study, there is no association between advanced HIV disease marked by CD4 count, duration of HIV, ART regimen, clinical stage of HIV and the experience of fatigue when adjusted for the other independent variables in the regression model. Although drugs like zidovudine and didanosine are frequently reported to have fatigue as side effects. ${ }^{40}$ Antiretroviral agents might help the control of viral replication and slower disease progression, which could mitigate the risk of fatigue associated with ART. Further, the distinct 
Table 2 Clinical characteristics of people living with HIV/AIDS attending antiretroviral therapy clinic at University of Gondar Hospital, University of Gondar, Northwest Ethiopia, 2019 ( $n=392)$

\begin{tabular}{|c|c|c|c|c|c|}
\hline \multirow[b]{2}{*}{ Variables } & \multirow{2}{*}{$\begin{array}{l}\text { Sample total } \\
\text { n (\%) }\end{array}$} & \multicolumn{2}{|c|}{ Fatigue $\mathrm{n}(\%)$} & \multirow[b]{2}{*}{$\chi^{2}$} & \multirow[b]{2}{*}{$P$ value } \\
\hline & & Yes & No & & \\
\hline \multicolumn{6}{|l|}{ Type of HAART regimen } \\
\hline $\mathrm{AZT}+3 \mathrm{TC}+\mathrm{NVP}$ & $155(39.5)$ & $74(47.7)$ & $81(52.3)$ & 1.3 & 0.7 \\
\hline $\mathrm{AZT}+3 \mathrm{TC}+\mathrm{EFV}$ & $16(4.1)$ & $7(43.8)$ & $9(56.2)$ & & \\
\hline TDF+3TC+EFV & $118(30.1)$ & $76(64.4)$ & $62(35.6)$ & & \\
\hline TDF+3TC+NVP & $63(16.1)$ & 27 (42.9) & $36(57.1)$ & & \\
\hline$A B C+D D I+L P V / R$ & $19(4.8)$ & $14(73.7)$ & $05(26.3)$ & & \\
\hline Pre-HAART & $21(5.4)$ & $11(52.4)$ & $10(47.6)$ & & \\
\hline \multicolumn{6}{|l|}{ CD4 counts } \\
\hline$<200$ cells $/ \mathrm{mm}^{3}$ & $23(5.8)$ & $07(30.4)$ & $16(69.6)$ & 4.5 & 0.23 \\
\hline 200-350 cells $/ \mathrm{mm}^{3}$ & $228(58.2)$ & $128(56.1)$ & $100(43.9)$ & & \\
\hline$>350$ cells $/ \mathrm{mm}^{3}$ & $141(36.0)$ & $73(51.8)$ & $68(48.2)$ & & \\
\hline \multicolumn{6}{|l|}{ Duration of HIV infection } \\
\hline$<60$ months & $232(59.2)$ & $176(75.9)$ & $56(24.1)$ & 119.7 & 0.000 \\
\hline 60-100 months & $87(22.2)$ & $24(27.6)$ & $63(72.4)$ & & \\
\hline$>100$ months & $73(18.6)$ & $09(12.3)$ & $64(87.7)$ & & \\
\hline \multicolumn{6}{|c|}{ WHO HIV/AIDS clinical stage } \\
\hline Stage I & $230(58.7)$ & $99(43)$ & $131(57)$ & 25.1 & 0.00 \\
\hline Stage II & $80(20.4)$ & $51(63.8)$ & 29 (36.2) & & \\
\hline Stage III & $81(20.7)$ & $58(71.6)$ & $23(28.4)$ & & \\
\hline Stage IV & $1(0.3)$ & $01(100)$ & $0(0)$ & & \\
\hline \multicolumn{6}{|l|}{ Weight loss } \\
\hline No weight loss & $26(6.6)$ & $24(92.3)$ & $02(7.7)$ & 31.9 & 0.01 \\
\hline Mild weight loss & $148(37.8)$ & $102(68.9)$ & $46(31.1)$ & & \\
\hline Moderate weight loss & $122(31.1)$ & $63(51.6)$ & $59(48.4)$ & & \\
\hline Severe weight loss & $96(24.5)$ & $20(20.8)$ & $76(79.2)$ & & \\
\hline \multicolumn{6}{|l|}{ Anaemic } \\
\hline Yes & $191(48.7)$ & $180(94.2)$ & $11(5.8)$ & 111.2 & 0.000 \\
\hline No & $201(51.3)$ & $29(14.4)$ & $172(85.6)$ & & \\
\hline \multicolumn{6}{|l|}{ Diabetes mellitus } \\
\hline Yes & $18(4.6)$ & $15(83.3)$ & $03(16.7)$ & 13.6 & 0.001 \\
\hline No & $374(95.4)$ & $194(51.9)$ & $180(48.1)$ & & \\
\hline \multicolumn{6}{|l|}{ Hypertension } \\
\hline Yes & $11(9.4)$ & $10(90.8)$ & $01(9.1)$ & 9.2 & 0.002 \\
\hline No & 381 (89.6) & $198(52)$ & $183(48)$ & & \\
\hline \multicolumn{6}{|c|}{ Other comorbid conditions } \\
\hline Yes & $37(9.4)$ & $23(62.2)$ & $14(37.8)$ & 15.3 & 0.000 \\
\hline No & $355(90.6)$ & $186(52.4)$ & $169(47.6)$ & & \\
\hline \multicolumn{6}{|l|}{ Depression } \\
\hline Yes & 283 & $204(72.1)$ & $79(27.9)$ & 144.8 & 0.000 \\
\hline No & $109(28.1)$ & $21(19.3)$ & $88(80.7)$ & & \\
\hline \multicolumn{6}{|l|}{ Insomnia } \\
\hline Yes & 91 (23.2) & $43(47.3)$ & $48(52.7)$ & 1.66 & 0.68 \\
\hline No & 30 (76.8) & 166 (55.1) & 135 (44.9) & & \\
\hline
\end{tabular}


Table 2 Continued

\begin{tabular}{|c|c|c|c|c|c|}
\hline \multirow[b]{2}{*}{ Variables } & \multirow{2}{*}{$\begin{array}{l}\text { Sample total } \\
\text { n (\%) }\end{array}$} & \multicolumn{2}{|c|}{ Fatigue $\mathrm{n}(\%)$} & \multirow[b]{2}{*}{$\chi^{2}$} & \multirow[b]{2}{*}{$P$ value } \\
\hline & & Yes & No & & \\
\hline \multicolumn{6}{|c|}{ Physical activity } \\
\hline Yes & 117 (29.8) & $41(35.1)$ & 76 (64.9) & 5.49 & 0.014 \\
\hline No & $275(70.2)$ & $178(64.7)$ & $97(35.3)$ & & \\
\hline \multicolumn{6}{|c|}{ Physical disability } \\
\hline Yes & $12(3.1)$ & 10 (83.3) & $02(16.7)$ & 2.48 & 0.59 \\
\hline No & 380 (96.9) & 199 (52.4) & $181(47.8)$ & & \\
\hline
\end{tabular}

HAART, highly active antiretroviral therapy.

difference between the perception of fatigue and performance fatigue, level of fatigue and energy demand of the respondents could have influenced the findings. ${ }^{41}$ Then again, the finding of this result was lower than the findings reported in other studies done in a rural district in South-west Uganda $61 \%,{ }^{42}$ South Africa $66.7 \%,{ }^{37}$ Rochester, USA $64 \%,{ }^{43}$ China $86.8 \%{ }^{44}$ and the UK $65.1 \%{ }^{45}$ This discrepancy might be due to the reasons that the Ugandan and the USA included lesser samples 212 and 128, respectively. Moreover, the Ugandan study used Memorial Symptom Assessment Scale-Short Form, the UK used a self-administered questionnaire with Chalder Fatigue Scale to measure fatigue, though the study from the USA used similar outcome measure (FSS) the cutoff was lower, the study in South Africa used convenient sampling to report multiple self-reported symptoms with fatigue being one among those. The Chinese study was based on the secondary source data (case-report form) using a retrospective design. Overall, the variations in the sampling method, study design, outcome tools, data collection method and clinical characteristics of the patients could explain these discrepancies.

In this study, the key predictors that were significantly associated with fatigue among adult people living with HIV were clinically diagnosed anaemia, low income, parity, weight loss, depression and living without a spouse. Likewise, studies done in the USA and China reported an association between fatigue and anaemia. ${ }^{4446}{ }^{47}$ Fatigue is the cardinal symptom of anaemia, a prognostic marker of disease progression, and frequently reported as a predictor of morbidity and mortality among people living with HIV. The negative effects of HIV infection and cART on the haematopoiesis contribute to low haemoglobin concentration leading to impaired oxygen transport to

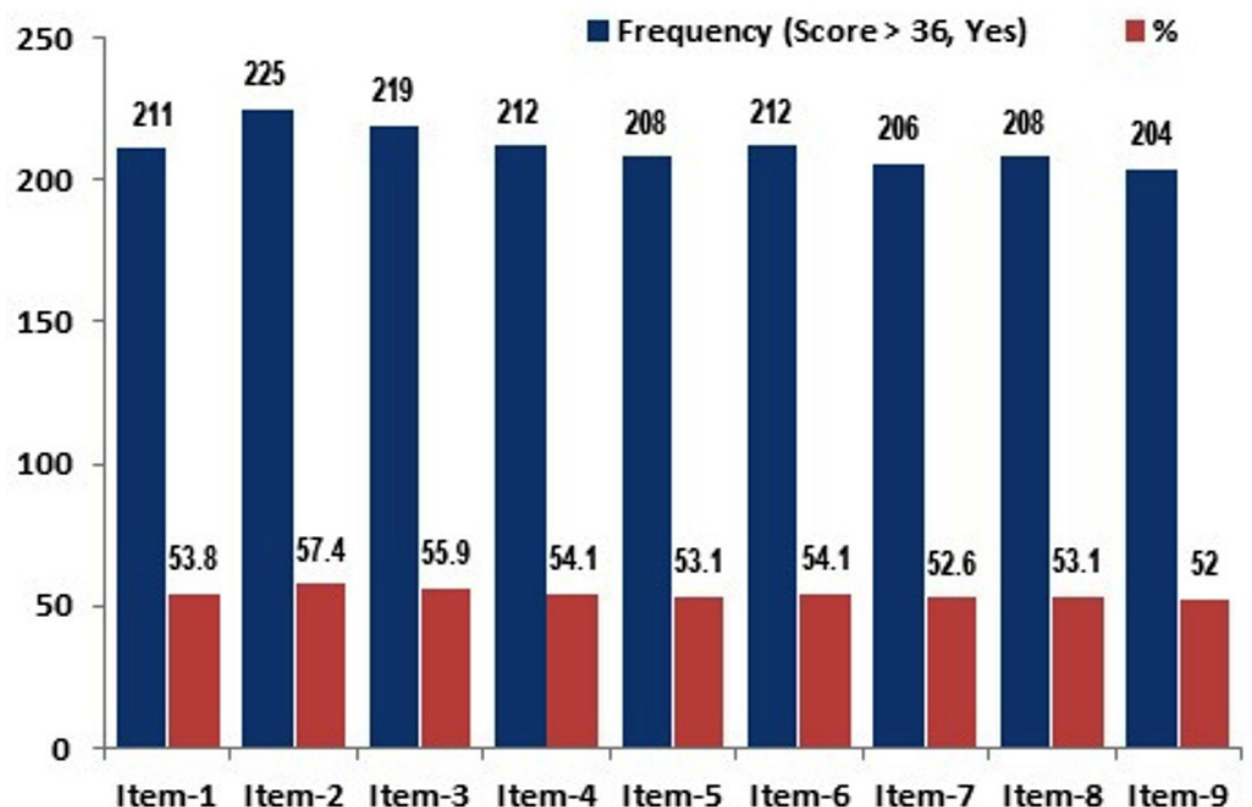

Figure 1 Frequency distribution of fatigue characteristics based on 9-item Fatigue Severity Scale (FSS) of HIV infected attending antiretroviral therapy (ART) clinics in the University of Gondar Specialized Comprehensive Hospital, Northwest Ethiopia, 2019 ( $n=392)$. 9-items FSS: Item-I, my motivation is lower when I am fatigued; Item-2, exercise brings on my fatigue; Item-3, I am easily fatigued; Item-4, fatigue interferes with my physical functioning; Item-5, fatigue causes frequent problems for me; Item-6, my fatigue prevents sustained physical functioning; Item-7, fatigue interferes with carrying out certain duties; Item8 , fatigue is among my three most disabling symptoms; Item-9, fatigue interferes with my work, family or social life. 
Table 3 Univariate and multivariable analysis for the associated and predicting sociodemographic and clinical characteristics to HIV-related fatigue, 2019 ( $n=392)$, Ethiopia

\begin{tabular}{|c|c|c|c|c|}
\hline \multirow[b]{2}{*}{ Variables } & \multicolumn{2}{|c|}{ Fatigue } & \multirow{2}{*}{$\begin{array}{l}\text { Univariate } \\
\text { COR }(95 \% \mathrm{Cl})\end{array}$} & \multirow{2}{*}{$\begin{array}{l}\text { Multivariable } \\
\text { AOR }(95 \% \mathrm{Cl})\end{array}$} \\
\hline & Yes & No & & \\
\hline \multicolumn{5}{|l|}{ Sex } \\
\hline Women & 173 & 86 & $5.42(3.45 \text { to } 8.6)^{\star}$ & 2.61 (1.01 to 5.32$)^{\star}$ \\
\hline Men & 36 & 97 & 1 (ref) & 1 (ref) \\
\hline \multicolumn{5}{|l|}{ Marital status } \\
\hline Single & 44 & 47 & 1 (ref) & 1 (ref) \\
\hline Married & 112 & 91 & $1.32(0.80 \text { to } 2.16)^{\star}$ & $0.18(0.10 \text { to } 0.9)^{\star}$ \\
\hline Divorced & 35 & 40 & $0.94(0.51 \text { to } 1.72)^{\star}$ & 0.24 (0.07 to 2.2 ) \\
\hline Widowed & 18 & 5 & $3.85(1.32 \text { to } 11.24)^{\star}$ & 0.77 (0.14 to 3.1$)$ \\
\hline \multicolumn{5}{|l|}{ Income } \\
\hline Low income & 147 & 23 & $133.15(52.56$ to 337.3$)$ * & $7.1(4.6 \text { to } 22.15)^{\star}$ \\
\hline Medium income & 56 & 35 & 33.33 (13.26 to 83.78$)$ & 2.51 (1.60 to 18.76 ) \\
\hline High income & 6 & 125 & 1 (ref) & 1 (ref) \\
\hline \multicolumn{5}{|l|}{ Educational status } \\
\hline Illiterate & 68 & 46 & $1.6(0.81 \text { to } 3.21)^{\star}$ & 0.54 (0.12 to 1.99$)$ \\
\hline Grade 1-6 & 38 & 44 & 0.94 (0.46 to 1.94$)$ & 0.86 (0.52 to 2.01$)$ \\
\hline Grade 7-8 & 30 & 23 & 1.42 (0.64 to 3.15$)$ & $0.13(0.09,1.00)$ \\
\hline Grade 9-10 & 32 & 21 & $1.66(0.75$ to 3.7$)$ & 0.21 (0.14 to 1.42$)$ \\
\hline Grade 11-12 & 19 & 25 & $0.83(0.36$ to 1.9$)$ & 0.73 (0.31 to 3.6$)$ \\
\hline Diploma and above & 22 & 24 & 1 (ref) & 1 (ref) \\
\hline \multicolumn{5}{|l|}{ Occupation status } \\
\hline Employed & 52 & 154 & 1 (ref) & 1 (ref) \\
\hline Unemployed & 157 & 29 & $16.033(9.67 \text { to } 26.59)^{\star}$ & $2.79(1.19 \text { to } 9.84)^{\star}$ \\
\hline \multicolumn{5}{|l|}{ Having children } \\
\hline Yes & 182 & 61 & $13.48(8.11 \text { to } 22.40)^{\star}$ & $4.87(2.18 \text { to } 17.95)^{\star}$ \\
\hline No & 27 & 122 & 1 (ref) & 1 (ref) \\
\hline \multicolumn{5}{|l|}{ Anaemia } \\
\hline Yes & 180 & 11 & $17.05(7.01 \text { to } 28.3)^{\star}$ & $12.45(5.61 \text { to } 41.01)^{\star}$ \\
\hline No & 29 & 172 & 1 (ref) & 1 (ref) \\
\hline \multicolumn{5}{|l|}{ Depression } \\
\hline Yes & 204 & 79 & $5.61(2.03 \text { to } 19.1)^{*}$ & $4.51(1.91 \text { to } 11.20)^{\star}$ \\
\hline No & 21 & 88 & 1 ref & 1 ref \\
\hline \multicolumn{5}{|l|}{ Weight loss } \\
\hline No weight loss & 6 & 20 & 1 (ref) & 1 (ref) \\
\hline Mild weight loss & 109 & 39 & $12.3(3.24 \text { to } 24.22)^{\star}$ & $4.2(2.56 \text { to } 13.94)^{\star}$ \\
\hline Moderate weight loss & 99 & 23 & $13.9(2.89 \text { to } 27.5)^{\star}$ & $5.1(1.85 \text { to } 16.12)^{\star}$ \\
\hline Severe weight loss & 45 & 51 & $7.8(1.01 \text { to } 15.2)^{\star}$ & 1.85 (0.79 to 7.63$)$ \\
\hline \multicolumn{5}{|l|}{ Comorbid condition } \\
\hline Yes & 37 & 9 & $4.16(1.95 \text { to } 8.88)^{\star}$ & 4.71 (1.10 to 18.21$)$ \\
\hline No & 172 & 174 & 1 (ref) & 1 (ref) \\
\hline
\end{tabular}

*Level of significance $p<0.05$

*Significant association of the characteristics with HIV-related fatigue in the multivariable model.

AOR, adjusted OR; COR, Crude Odds Ratio. 
the vital organs and musculoskeletal system resulting in fatigue. The resolution of HIV-related anaemia has been shown to improve fatigue among individuals living with $\mathrm{HIV}^{48}$

Depression is significantly associated with fatigue, low energy or tiredness itself is a depressive symptom. Similar to this study, many studies and a systematic review of 42 studies reported that inadequate income, unemployment and depression are stronger predictors and uniformly associated with HIV-related fatigue. ${ }^{13} 364950$ Less energy, lack of work capacity, an inclination to work and reduced motivation may eventually result in unemployment and inadequate income. Importantly, fatigue that precedes depression or results from depression is a distinct health outcome among people living with HIV and the interaction can sometimes become a vicious cycle. Further, the negative cognitions about side effects, medical sequelae of HIV, opportunistic infections and fear of impending mortality could increase the likelihood of depressionrelated symptoms. The present study also found that female patients were more likely to perceive fatigue than men. This finding is similar to the studies conducted in South Africa, ${ }^{37}$ France, ${ }^{51}$ and a systematic review. ${ }^{13}$ The mean age of women in this was lower than men, the majority of those who were diagnosed with anaemia and weight loss were women. Besides, a higher representation of women in this study could have favoured this association. Furthermore, studies had reported that depression and fatigue to be highly prevalent among people living with HIV than the HIV-negative population. ${ }^{52} 53$ Fatigue and depression among people living with HIV might be clinically diverse from the same primary symptoms among HIV negative population, thus requiring a different management approach.

In this study, having children was associated with the experience of fatigue. A similar association was reported by studies in the USA, France and South Africa. ${ }^{36} 5054$ The findings might be attributed to additional responsibility and workload in terms of the physical, social and financial burden that are associated with having children. However, participants who were married and living with their spouse was a protective factor for fatigue than those who lived without a spouse. Emotional stress, grief, loneliness and depression attributed to the loss of spouse, separation and lack of support could be the possible explanation for likely risk of fatigue among those living alone. Moreover, people living with HIV are likely to be widowed, divorced and/or singled compared with HIV negative patients leading to bereavement and diminished support. ${ }^{52}$

The current study also found that mild and moderate weight loss was significantly associated with fatigue. This was similar to the studies done in Eastern Cape, Bellville, South Africa ${ }^{37}$ and Southwest Uganda. ${ }^{42}$ Although the association between fatigue and severe weight loss is non-significant, the coefficient above 1 in the regression model explains the risk of fatigue. Malnourishment, wasting, loss of appetite, side-effects of drugs, illness related to coinfections and HIV-related complications are blamed for unexplained weight loss among people living with HIV. Each of these factors can cause loss of energy and/or tiredness and are predictors or risk factors for developing fatigue. Another important finding in this study is that there was a high rate of unemployment and low income among the people living with HIV in agreement with several studies and similarly these populations are more likely to experience fatigue. Further, unemployment has been known to compound fatigue and depression. 195255

While the high prevalence of self-reported fatigue in this study compared with the western studies and association with anaemia, weight loss, depression, low income and having children has implications for the clinical management and policy management of fatigue in HIVinfected patients. First, health-related attitudes, culture, beliefs and high altitude of the study area might describe the higher reporting of fatigue. Second, the symptom of fatigue should prompt not only a search for clinical causes, but also detailed questioning about socioeconomic, cultural and psychological causes. Given the high prevalence, and seemingly negative consequences of HIV-related fatigue on the quality of life and functional capacity in these individuals, there is a need for preventive measures, patient education, interventions and further evaluation of the clinical, psycho-social and cultural factors in the Ethiopian adults living with HIV.

\section{CONCLUSION}

The prevalence of fatigue was found to be high in people living with HIV/AIDS. From all the sociodemographic factors and HIV/AIDS-related medical factors that were studied, being women, being married, low income, unemployed, having children, severe weight loss and anaemia were found statistically associated with fatigue. Hence, early detection of the HIV-related fatigue and its underlying treatable causes permits patient education, controlling risk factors and treat these conditions when they are present or predisposed.

Acknowledgements First, we would like to express our deepest gratitude to the University of Gondar for ethical approval and fully funding this project. Our gratitude and appreciation go to data collectors, adults living with HIV attending HIV care clinic who participated in this study. We are also grateful to all the hospital authorities and HIV care clinic staff for their cooperation.

Contributors MBaye brought the original idea and was involved in the proposal writing, designed the study and participated in all the implementation stages of the project. MBaye and BJ analysed the data and wrote the manuscript. BF, BJ, SMA and MBayisa participated in the conception of the original idea and were involved in the proposal writing, finalised the write-up of the manuscript and critically revised the manuscript for important intellectual content. BJ, MBaye, SMA, MBayisa and BF were responsible for critically revising the research proposal and the manuscript, and participated in its design and interpretation. BJ and MBayisa were involved in the design of the work and approved the version to be published. All the authors read and approved the final version of the manuscript.

Funding This study was funded by the University of Gondar (Grant ref no: 08792017). The views presented in the article are the authors and do not necessarily express the views of the funding organisation. University of Gondar did not involve in the design of the study, data collection, analysis and interpretation. 
Competing interests None declared.

Patient consent for publication Not required.

Ethics approval The study was conducted after submitting the study protocol followed by ethical approval from the Institutional Review Board (IRB), CMHS, University of Gondar (Ref no; SOM/087/9/2017). Permissions were obtained from the regional public health institute and the authorities of the study site before the study. Written consent was obtained from each participant after explaining the study, its objective, benefits, and its importance. Information's were recorded anonymously and confidentiality and beneficence were assured throughout the study period.

Provenance and peer review Not commissioned; externally peer reviewed.

Supplemental material This content has been supplied by the author(s). It has not been vetted by BMJ Publishing Group Limited (BMJ) and may not have been peer-reviewed. Any opinions or recommendations discussed are solely those of the author(s) and are not endorsed by BMJ. BMJ disclaims all liability and responsibility arising from any reliance placed on the content. Where the content includes any translated material, BMJ does not warrant the accuracy and reliability of the translations (including but not limited to local regulations, clinical guidelines, terminology, drug names and drug dosages), and is not responsible for any error and/or omissions arising from translation and adaptation or otherwise.

Open access This is an open access article distributed in accordance with the Creative Commons Attribution Non Commercial (CC BY-NC 4.0) license, which permits others to distribute, remix, adapt, build upon this work non-commercially, and license their derivative works on different terms, provided the original work is properly cited, appropriate credit is given, any changes made indicated, and the use is non-commercial. See: http://creativecommons.org/licenses/by-nc/4.0/.

\section{ORCID iDs}

Solomon Mekonnen Abebe http://orcid.org/0000-0002-1150-2319

Balamurugan Janakiraman http://orcid.org/0000-0003-3866-9351

\section{REFERENCES}

1 UNAIDS. Global HIV \& AIDS statistics - 2019 fact sheet. Available: https://www.unaids.org/en/resources/fact-sheet [Accessed 06 Jun 2020].

2 UNFPA Ethiopia. HIV prevention in Ethiopia: national road map (2018-2021), 2018. Available: https://ethiopia.unfpa.org/en/ publications/hiv-prevention-ethiopia-national-road-map-2018-2021 [Accessed 06 Jun 2020].

3 OIT. Ethiopian strategic plan for Intensifying Multisectoral HIV/ AIDS response 2004-2008. Available: https://www.ilo.org/wcmsp5/ groups/public/---ed_protect/---protrav/---ilo_aids/documents/ legaldocument/wcms_125381.pdf [Accessed 06 Jun 2020].

4 Devex. Federal HIV/AIDS prevention and control office (HAPCO). Available: https://www.devex.com/organizations/federal-hiv-aidsprevention-and-control-office-hapco-51407 [Accessed 06 Jun 2020].

5 Kibret GD, Ferede A, Leshargie CT, et al. Trends and spatial distributions of HIV prevalence in Ethiopia. Infect Dis Poverty 2019;8:90.

6 Kluger BM, Krupp LB, Enoka RM. Fatigue and fatigability in neurologic illnesses: proposal for a unified taxonomy. Neurology 2013;80:409-16.

7 van't Leven M, Zielhuis GA, van der Meer JW, et al. Fatigue and chronic fatigue syndrome-like complaints in the general population. Eur J Public Health 2010;20:251-7.

8 Perazzo JD, Webel AR, Voss JG, et al. Fatigue symptom management in people living with human immunodeficiency virus. $J$ Hosp Palliat Nurs 2017;19:122-7.

9 Gallant JE. 100 Questions \& Answers about HIV and AIDS. Jones \& Bartlett Publishers, 2016.

10 Loades ME, Coetzee B, Du Toit S, et al. ' ... But i'm still tired': the experience of fatigue among South African adolescents receiving antiretroviral therapy. AIDS Care 2018;30:746-50.

11 Croxford S, Kitching A, Desai S, et al. Mortality and causes of death in people diagnosed with HIV in the era of highly active antiretroviral therapy compared with the general population: an analysis of a national observational cohort. Lancet Public Health 2017;2:e35-46.

12 Zuniga JM, Whiteside A, Ghaziani A. A decade of HAART: the development and global impact of highly active antiretroviral therapy. Oxford University Press, 2009.

13 Jong E, Oudhoff LA, Epskamp C, et al. Predictors and treatment strategies of HIV-related fatigue in the combined antiretroviral therapy era. AIDS 2010;24:1387-405.
14 Payne BAI, Hateley CL, Ong ELC, et al. Hiv-Associated fatigue in the era of highly active antiretroviral therapy: novel biological mechanisms? HIV Med 2013;14:247-51.

15 Barroso J, Voss JG. Fatigue in HIV and AIDS: an analysis of evidence. J Assoc Nurses AIDS Care 2013;24:S5-14.

16 Barroso J, Harmon JL, Madison JL, et al. Intensity, chronicity, circumstances, and consequences of HIV-related fatigue: a longitudinal study. Clin Nurs Res 2014;23:514-28.

17 Gebreyesus T, Belay A, Berhe G, et al. Burden of fatigue among adults living with HIV/AIDS attending antiretroviral therapy in Ethiopia. BMC Infect Dis 2020;20:1-10.

18 George Dalmida S, McDonnell Holstad M, Fox R, et al. Depressive symptoms and fatigue as mediators of relationship between poor sleep factors and medication adherence in HIV-positive women. Journal of Research in Nursing 2015;20:499-514.

19 Wagener MN, van Opstal SEM, Miedema HS, et al. Employmentrelated concerns of HIV-positive people in the Netherlands: input for a multidisciplinary guideline. J Occup Rehabil 2014;24:790-7.

20 Barroso J, Carlson JR, Meynell J. Physiological and psychological markers associated with HIV-related fatigue. Clin Nurs Res 2003;12:49-68.

21 Camlin CS, Neilands TB, Odeny TA, et al. Patient-Reported factors associated with reengagement among HIV-infected patients disengaged from care in East Africa. AIDS 2016;30:495.

22 Barroso J, Hammill BG, Leserman J, et al. Physiological and psychosocial factors that predict HIV-related fatigue. AIDS Behav 2010;14:1415-27.

23 Voss JG, Dodd M, Portillo C, et al. Theories of fatigue: application in HIV/AIDS. J Assoc Nurses AIDS Care 2006;17:37-50.

24 Schnall R, Cho $\mathrm{H}$, Mangone A, et al. Mobile health technology for improving symptom management in low income persons living with HIV. AIDS Behav 2018;22:3373-83.

25 Haile TG, Engeda EH, Abdo AA. Compliance with standard precautions and associated factors among healthcare workers in Gondar university comprehensive specialized Hospital, Northwest Ethiopia. J Environ Public Health 2017;2017:1-8.

26 Adem KS, Janakiraman B, Gebremeskel BF, et al. Epidemiology and factors associated with peripheral neuropathy among HIV infected patients in Gondar, Ethiopia: a cross-sectional study. PLoS One 2019;14:e0211354

27 Charan J, Biswas T. How to calculate sample size for different study designs in medical research? Indian J Psychol Med 2013;35:121.

28 Krupp LB, LaRocca NG, Muir-Nash J, et al. The fatigue severity scale. Application to patients with multiple sclerosis and systemic lupus erythematosus. Arch Neurol 1989;46:1121-3.

29 Valko PO, Bassetti CL, Bloch KE, et al. Validation of the fatigue severity scale in a Swiss cohort. Sleep 2008;31:1601-7.

30 Lerdal A, Kottorp A, Gay C, et al. A 7-item version of the fatigue severity scale has better psychometric properties among HIVinfected adults: an application of a Rasch model. Qual Life Res 2011;20:1447-56.

31 Webel AR, Perazzo J, Decker M, et al. Physical activity is associated with reduced fatigue in adults living with HIV/AIDS. J Adv Nurs 2016;72:3104-12.

32 Manea L, Gilbody S, McMillan D. Optimal cut-off score for diagnosing depression with the patient health questionnaire (PHQ-9): a meta-analysis. CMAJ 2012;184:E191-6.

33 McLean E, Cogswell M, Egli I, et al. Worldwide prevalence of anaemia, who vitamin and mineral nutrition information system, 1993-2005. Public Health Nutr 2009;12:444-54.

34 Sousa VD, Zauszniewski JA, Musil CM. How to determine whether a convenience sample represents the population. Appl Nurs Res 2004;17:130-3

35 Evans S, Li L. A comparison of goodness of fit tests for the logistic Gee model. Stat Med 2005;24:1245-61.

36 Voss JG, Sukati NA, Seboni NM, et al. Symptom burden of fatigue in men and women living with HIV/AIDS in southern Africa. $J$ Assoc Nurses AIDS Care 2007;18:22-31.

37 Peltzer K, Phaswana-Mafuya N. The symptom experience of people living with HIV and AIDS in the eastern Cape, South Africa. BMC Health Serv Res 2008;8:271.

38 Simoni JM, Safren SA, Manhart LE, et al. Challenges in addressing depression in HIV research: assessment, cultural context, and methods. AIDS Behav 2011;15:376-88.

39 Gebrekidan Abbay A, Tibebe Mulatu A, Azadi H. Community knowledge, perceived beliefs and associated factors of mental distress: a case study from Northern Ethiopia. Int J Environ Res Public Health 2018;15:2423.

40 Chen W-T, Shiu C-S, Yang JP, et al. Antiretroviral therapy (art) side effect impacted on quality of life, and depressive symptomatology: a mixed-method study. J AIDS Clin Res 2013;4:218. 
41 Enoka RM, Duchateau J. Translating fatigue to human performance. Med Sci Sports Exerc 2016;48:2228-38.

42 Wakeham K, Harding R, Bamukama-Namakoola D, et al. Symptom burden in HIV-infected adults at time of HIV diagnosis in rural Uganda. J Palliat Med 2010;13:375-80.

43 Schifitto G, Deng L, Yeh T-M, et al. Clinical, laboratory, and neuroimaging characteristics of fatigue in HIV-infected individuals. $J$ Neurovirol 2011;17:17-25.

44 Liu Z, Yang J, Liu H, et al. Factors associated with fatigue in acquired immunodeficiency syndrome patients with antiretroviral drug adverse reactions: a retrospective study. J Tradit Chin Med 2013;33:316-21.

45 Henderson M, Safa F, Easterbrook P, et al. Fatigue among HIVinfected patients in the era of highly active antiretroviral therapy. HIV Med 2005;6:347-52.

46 Sullivan PS, Dworkin MS. Adolescent spectrum of HIV disease Investigators. prevalence and correlates of fatigue among persons with HIV infection. Journal of Pain and Symptom Management 2003;25:329-33.

47 Goswami U, Baker JV, Wang Q, et al. Sleep apnea symptoms as a predictor of fatigue in an urban HIV clinic. AIDS Patient Care STDS 2015;29:591-6.
48 Belperio PS, Rhew DC. Prevalence and outcomes of anemia in individuals with human immunodeficiency virus: a systematic review of the literature. Am J Med 2004;116 Suppl 7A:27-43.

49 Harmon JL, Barroso J, Pence BW, et al. Demographic and illnessrelated variables associated with HIV-related fatigue. J Assoc Nurses AIDS Care 2008;19:90-7.

50 Voss JG. Predictors and correlates of fatigue in HIV/AIDS. J Pain Symptom Manage 2005;29:173-84.

51 Bergamaschi A, d'Arripe-Longueville F, Gray LL, et al. Perceived HIV-related physical fatigue, sociodemographic characteristics and physical activity: a cross-sectional study. J Clin Nurs 2019;28:2147-56.

52 Akena DH, Musisi S, Kinyanda E. A comparison of the clinical features of depression in HIV-positive and HIV-negative patients in Uganda. Afr J Psychiatry 2010;13:43-51.

53 Marion I, Antoni M, Pereira D, et al. Distress, sleep difficulty, and fatigue in women co-infected with HIV and HPV. Behav Sleep Med 2009;7:180-93.

54 Meynell J, Barroso J. Bioimpedance analysis and HIV-related fatigue. $J$ Assoc Nurses AIDS Care 2005;16:13-22.

55 Kocalevent RD, Hinz A, Brähler E, et al. Determinants of fatigue and stress. BMC Res Notes 2011;4:238. 